\title{
РЕЗУЛЬТАТИ ОЦІНКИ РІВНОВАГИ У ПАЦІЕНТІВ ПІСЛЯ ЛАПАРОСКОПІЧНОЇ ХОЛЕЦИСТЕКТОМІЇ НА СТАЦІОНАРНОМУ ЕТАПІ РЕАБІЛІТАЦІЇ
}

\author{
Н.Р. Голод ${ }^{1}$, І.К. Чурпій${ }^{1}$ С.О. Кулібаба ${ }^{2}$ \\ ${ }^{1}$ Івано-Франківський національний медичний університет, кафедра фізичної реабілітації, ерготерапії \\ та фізичного виховання, Україна, \\ ORCID ID: 0000-0003-0996-6920, \\ ORCID ID: 0000-0003-1735-9418, \\ e-mail: natasha_777@i.ua \\ ${ }^{2}$ Вінницький найіональний медичний університет ім. М.I. Пирогова, кафедра фізичного виховання та \\ ЛФК, м. Вінниця, Украӥна, \\ ORCID ID: 0000-0002-1717-8097, \\ e-mail: kulibabasergij@gmail.com
}

Резюме. Мета дослідження. Визначити ризик падінь пацієнтів після ЛХЕ на стаціонарному етапі реабілітації за допомогою шкали Берген.

Матеріали і методи. У дослідженні взяли участь 30 пацієнтів після ургентної холецистектомії і 30 після планової холецистектомії, які перебували на стаціонарному лікуванні у хірургічному відділенні ІваноФранківської центральної міської клінічної лікарні. Оцінку рівноваги проводили, застосовуючи Шкалу Берген (BERGBALANCESCALE - BBS), на другу і на четверту доби після оперативного втручання.

Висновки:

1. У порівнянні із іншими тестами, шкала рівноваги Берга зарекомендувала себе як найбільш переконливий функціональний тест виявлення дисфункцій рівноваги i, на нашу думку, може послужити хорошим інструментом для встановлення індивідуальних цілей у програмі фізичної терапії для пацієнтів після ЛХЕ.

2. У ранньому післяопераційному періоді (на 2 добу після оперативного втручання) пацієнти мають виражений ступінь порушення рівноваги, який обумовлений віком та наявністю супутньої патології, більш виражений у пацієнтів після ургентної холецистектомії.

3. Оцінка рівноваги на 4 день після оперативного втручання вказує на позитивну динаміку $($ р $<0,05)$, тобто покращення функції, проте ступінь ризику падінь залишається ще досить високим.

4. Високий рівень падіння на стаціонарному етапі реабілітації пацієнтів після лапароскопічної холецистектомії обумовлює необхідність включення у програму фізичної терапії як на стаціонарному, так і на амбулаторному етапах реабілітації методів та засобів, направлених на відновлення функції рівноваги, зміцнення тих м’язів, які відповідальні за постуральну стабільність.

Ключові слова: лапароскопічна холецистектомія, оцінка рівноваги, реабілітація.

Вступ. Жовчнокам'яна хвороба (ЖКХ) - одне 3 найпоширеніших захворювань людства. За даними різних авторів, на ЖКХ страждає 10-20\% дорослого населення країн Європи. На жовчнокам'яну хворобу страждає кожна п'ята жінка та кожний десятий чоловік після 50 років. Біля чверті населення старше 60 років мають жовчні конкременти. Результати епідеміологічних досліджень свідчать про те, що кількість хворих на цю патологію кожні 10 років збільшується вдвічі (Marshall H.U., Einarsson C., Ільченко А.А.). Дані VI Всесвітнього конгресу гастроентерологів свідчать, що ЖКХ за поширеністю поступається лише атеросклерозу та $є$ приводом для щорічного проведення у світі до 2,5 мільйонів планових та екстрених операцій на жовчовивідних шляхах.

Досягнення науки і техніки зумовили наявність точної діагностики та швидкого лікування пацієнта при максимально короткому терміні перебування хворого в стаціонарі. Перспективи в радикальному хірургічному лікуванні пацієнтів на ЖКХ 3'явились завдяки впровадженню в клінічну практику такої малотравматичної операції як лапароскопічна холецистектомія, яка забезпечує більш швидке одужання. Широке впровадження у клінічну практику лапароскопічної холецистектомії (ЛХЕ) - золотого стандарту лікування при ЖКХ - дозволило скоротити перебування хворих в умовах стаціонару в декілька разів. Цьому розділу хірургії присвячено значну кількість наукових розробок та публікацій, багато з яких про вдосконалення хірургічного та медикаментозного лікування хворих з ЖКХ та його вплив на біліарну систему людини.

Проте на даний час в Україні є недостатня кількість наукових праць 3 питань реабілітації хворих після. Більшість пацієнтів даного профілю після виписки зі стаціонару знаходиться в підгострому періоді протікання хвороби зі своїми проблемами без реабілітаційної допомоги кваліфікованих фахівців.

Обгрунтування дослідження. Згідно 3 затвердженим розпорядженням Кабінету Міністрів 
України від 27 грудня 2017 р. №1008-р «План заходів із впровадження в Україні Міжнародної класифікації функціонування, обмежень життєдіяльності та здоров'я та Міжнародної класифікації функціонування, обмежень життєдіяльності» очевидно, що необхідна нова сучасна концепція реабілітації, у тому числі і хворих 3 даною патологією. Такі хворі потребують якісної та диференційованої реабілітації із дотриманням міжнародної класифікації функціонування (МКФ) людини.

Хворі після ЛХЕ також потребують реабілітаційного втручання 3 урахуванням таких компонентів МКФ: ураження - проблеми у функціях чи структурах тіла, такі як істотне відхилення або втрата (м'язова слабкість, погана рівновага, порушення функції сну, депресія); обмеження діяльності - труднощі, які особа може мати у виконанні діяльності (труднощі руху, догляду за собою); обмеження участі - проблеми, які особа може мати в участі у життєвих ситуаціях (галузь домашніх обов'язків, суспільного, соціального та громадського життя).

Однією із важливих функцій, яка суттєво впливає на рухову дієздатність пацієнта після ЛХЕ, $є$ постуральна рівновага $[1,2]$. Для розробки програми фізичної терапії пацієнтів після ЛХЕ необхідні тести, які дадуть змогу оцінити здатність виконання повсякденних завдань, виявити рівень ризику падінь і також відобразити вплив тимчасової неповносправності на загальний стан здоров'я та якість життя пацієнта. Використання клінічних тестів для оцінки рівноваги пацієнтів у процесі фізичної терапії $є$ необхідним для формування цілей фізичної терапії та оцінки ефективності впровадженої програми реабілітації.

Для визначення рівня функції рівноваги фахівці рекомендують застосовувати клінічні шкали, які є простими і зручними у застосуванні та здатні виявити наявність або відсутність порушень, визначити ризик падінь [4].

Оцінка рівноваги тіла за допомогою клінічних шкал є найбільш простим способом оцінки статично-рухових функцій. Їх можна застосовувати для: виявлення наявності чи відсутності порушень статично-рухових функцій, визначення ризику падінь; визначення виду порушень рівноваги та ходьби як однієї з причини обмежень активності та зниження якості життя; визначення рівня ефективності проведеного реабілітаційного втручання [3].

Багатокомпонентні порядкові шкали можуть бути корисні в оцінці виконання простих повсякденних дій. Зазвичай такі шкали сортують за ступенем значимості виконання серії рухових тестів за шкалою від 3 до 5 або використовуючи секундомір, щоб визначити, наскільки довго випробовуваний може утримувати рівновагу в певній позі. Найбільш широко використовуються шкала рівноваги Берга і шкала «Орієнтована на виконання завдання оцінка мобільності» [1].

У численних дослідженнях виявлено високу міжрейтингову надійність шкали (Berg K, WoodDauphinee S, Williams JI., 1995; Bogle Thorbahn LD, Newton RA., 1996). Вік випробовуваних не корелює 3 показниками шкали. Літні випробовувані, які здатні стояти прямо протягом мінімум 60 секунд, на шкалі рівноваги Берга показували результати від 18 до 53 балів (170). Для групи 3 центральною вестибулярною дисфункцією показники шкали рівноваги Берга показали чутливість до змін. Показники нижче 45 і рівні або вище 45 відповідно відокремлювали літніх випробовуваних з ризиком падіння від тих, у кого немає цього ризику (BogleThorbahn LD, Newton RA., 1996). Залежно від значення цього порогового показника, чутливість і специфічність виявлення осіб з ризиком падіння значно варіюється: пороговий показник, рівний 40, дає чутливість і специфічність рівні $45 \%$ i $96 \%$ відповідно, у той час як пороговий показник рівний 50 робить показники чутливості і специфічності рівними відповідно $85 \%$ і 73 \%. У порівнянні 3 іншими тестами, шкала рівноваги Берга зарекомендувала себе як найбільш переконливий функціональний тест виявлення дисфункцій рівноваги i, на нашу думку, може послужити хорошим інструментом для встановлення індивідуальних цілей у програмі фізичної терапії для пацієнтів після ЛХЕ. Шкала Берген (BERGBALANCESCALE - BBS) включає 14 тестів, які вимагають від випробовуваних підтримувати положення різного ступеня складності і виконувати певні особливі завдання $[1,2]$.

Мета дослідження. Визначити ризик падінь пацієнтів після ЛХЕ на стаціонарному етапі реабілітації за допомогою шкали Берген.

Матеріали і методи. У дослідженні взяли участь 30 пацієнтів після ургентної холецистектомії і 30 після планової холецистектомії, які перебували на стаціонарному лікуванні у хірургічному відділенні Івано-Франківської центральної міської клінічної лікарні. Оцінку рівноваги проводили на другу добу після оперативного втручання та на 4 добу після оперативного втручання.

Критерії виключення - пацієнти 3 неврологічними супутніми захворюваннями, важкий стан пацієнта.

Оцінка в балах проводилася на підставі здатності пацієнта після ПХЕ виконати самостійно 14 завдань або зробити це відповідно до певних вимог часу i відстані. Кожен компонент оцінювався за п'ятибальною порядковою шкалою від 0 до 4, таким чином, сумарні бали варіювалися від 0 до 56. Тобто, чим вищий показник, тим вища якість виконання завдання і вищий ступінь рівноваги, відповідно менший ризик падінь. Зазвичай на проведення тесту «Оцінка за шкалою рівноваги Берга» (Berg Balance Scale - BBS) у пацієнта після ЛХЕ на стаціонарному етапі реабілітації займала не більше 15-17 хвилин.

Результати дослідження. За допомогою шкали рівноваги Берга оцінювалися такі функції:

1. Здатність вставати 3 положення «сидячи» (пацієнту необхідно встати, при можливості не використовувати руки для підтримки). 4 бали - здатність незалежно встати, не використовуючи руки і зберігати стійкість; 3 бали - здатність незалежно встати, використовуючи руки; 2 бали - здатність після кількох спроб незалежно встати, використовуючи руки; 1 бал - потреба легкої допомоги, для того щоб встати або зберігати рівновагу; 0 балів - потреба середньої або максимальної допомоги, для того щоб встати. Тестування даної активності у пацієнтів після ур- 
гентної холецистектомії на другу добу після оперативного втручання становила $1,95 \pm 0,25$ бала, а на четверту - 2,98 $\pm 0,35$ бала. У пацієнтів після планової холецистектомії на другу добу після оперативного втручання оцінка була $2,65 \pm 0,37$ бала, а на четверту $3,23 \pm 0,32$ бала.

2. Здатність стояти без підтримки оцінювалася таким чином (пацієнту необхідно було простояти дві хвилини без підтримки): 4 бали - здатність стояти 2 хвилини без підтримки; 3 бали - здатність стояти 2 хвилини під контролем; 2 бали - здатність стояти 30 секунд без підтримки; 1 бал - потрібно кілька спроб, щоб стояти 30 секунд без підтримки; 0 балів - неможливість витримати 30 секунд, стоячи без допомоги. Якщо досліджуваний спроможний витримати 2 хвилини, стоячи без підтримки, то пункт № 3 оцінювався у 4 бали. Тестування даної активності у пацієнтів після ургентної холецистектомії на другу добу після оперативного втручання становила 1,53 $\pm 0,21$ бала, а на четверту - 2,01 $\pm 0,32$ бала. У пацієнтів після планової холецистектомії на другу добу після оперативного втручання оцінка була $1,77 \pm 0,28$ бала, а на четверту - 2,54 $\pm 0,43$ бала.

3. Здатність сидіти без підтримки спини i опорою стопами на підлогу або на табурет, при цьому пацієнт повинен сидіти, не використовуючи руки протягом 2 хвилин. 4 бали - здатність впевнено сидіти 2 хвилини; 3 бали - здатність сидіти 2 хвилини при контролі; 2 бали - здатність сидіти 30 секунд; 1 бал - здатність сидіти 10 секунд; 0 балів - неможливість сидіти без підтримки 10 секунд. Тестування даної активності у пацієнтів після ургентної холецистектомії на другу добу після оперативного втручання становила $1,52 \pm 0,15$ бала, а на четверту - 2,04 $\pm 0,33$ бала. У пацієнтів після планової холецистектомії на другу добу після оперативного втручання оцінка була $1,78 \pm 0,17$ бала, а на четверту $-2,28 \pm 0,24$ бала.

4. Здатність сісти 3 положення стоячи. 4 бали - здатність впевнено сідати 3 мінімальним використанням рук; 3 бали - здатність сідати за допомогою рук; 2 бали - здатність сідати 3 опорою литкової ділянки на стілець; 1 бал - здатність сідати незалежно, але рух вниз не контролює; 0 балів - потреба в допомозі, для того щоб сісти. Тестування даної активності у пацієнтів після ургентної холецистектомії на другу добу після оперативного втручання становила $1,89 \pm 0,14$ бала, а на четверту - 2,26 $\pm 0,25$ бала. У пацієнтів після планової холецистектомії на другу добу після оперативного втручання оцінка була $2,56 \pm 0,22$ бала, а на четверту - 3,18 $\pm 0,31$ бала.

5. Пересаджування. Пацієнту необхідно пересісти $з$ одного стільця на інший, що стоїть поруч, двома шляхами: використовуючи підлокітники і без використання підлокітників. 4 бали - здатність впевнено пересідати 3 незначним використанням рук; 3 бали - здатність впевнено пересідати 3 використанням рук; 2 бали - здатність пересідати з усними порадами і / або контролем; 1 бал - потреба допомоги однієї людини; 0 балів - потреба двох чоловік для допомоги або контролю. Тестування даної активності у пацієнтів після ургентної холецистектомії на другу добу після оперативного втручання становила
$2,81 \pm 0,27$ бала, а на четверту - 3,25 $\pm 0,33$ бала. У пацієнтів після планової холецистектомії на другу добу після оперативного втручання оцінка була $3,02 \pm 0,37$ бала, а на четверту - 3,77 $\pm 0,40$ бала.

6. Здатність стояти без підтримки з закритими очима. Пацієнт повинен стояти з закритими очима протягом 10 секунд: 4 бали - здатність впевнено стояти 10 секунд; 3 бали - здатність стояти 10 секунд 3 контролем; 2 бали - здатність стояти 3 секунди; 1 бал - неможливість закрити очі на 3 секунди, але впевнене виконання; 0 балів - потреба в допомозі, для того щоб уникнути падіння. Тестування даної активності у пацієнтів після ургентної холецистектомії на другу добу після оперативного втручання становила

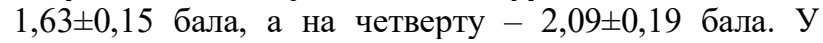
пацієнтів після планової холецистектомії на другу добу після оперативного втручання оцінка була $1,82 \pm 0,22$ бала, а на четверту - 3,01 $\pm 0,37$ бала.

7. Здатність стояти без підтримки зі стопами, зведеними разом. 4 бали - здатність стояти впевнено 1 хвилину; 3 бали - здатність стояти 1 хвилину з контролем; 2 бали - здатність стояти протягом 30 секунд; 1 бал - потреба в допомозі, для того щоб поставити разом стопи, але здатні встояти 15 секунд у необхідному положенні; 0 балів - потреба в допомозі, для того щоб поставити разом стопи і неможливість встояти 15 секунд у необхідному положенні. Тестування даної активності у пацієнтів після ургентної холецистектомії на другу добу після оперативного втручання становила $1,09 \pm 0,08$ бала, а на четверту $-1,47 \pm 0,21$ бала. У пацієнтів після планової холецистектомії на другу добу після оперативного втручання оцінка була

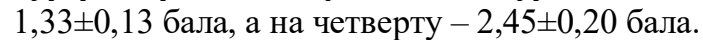

8. Нахил вперед 3 витягнутою рукою в положенні стоячи. Рука пацієнта повинна бути піднята на 90, потім необхідно витягнути пальці і дотягнутися вперед наскільки можливо. Дослідник розміщує лінійку у кінчиків пальців, коли рука піднята вперед. Пальці не повинні торкатися лінійки, при нахилі вперед. Реєструється відстань, на яку при нахилі вперед перемістилися кінчики пальців пацієнта. Ми просили пацієнта виконати тест, використовуючи обидві руки, щоб уникнути ротації хребта. 4 бали - може впевнено нахилитися вперед більш ніж на 25 см (10 дюймів); 3 бали - може нахилитися вперед більш ніж на $12.5 \mathrm{~cm}$ (5 дюймів); 2 бали -- може нахилитися вперед більш ніж на 5 см (2 дюйми); 1 бал - нахиляється вперед, але вимагає контролю; 0 балів -- падіння при спробі виконати тест / потрібна підтримка сторонньої особи. Тестування даної активності у пацієнтів після ургентної холецистектомії на другу добу після оперативного втручання становила $0,91 \pm 0,18$ бала, а на

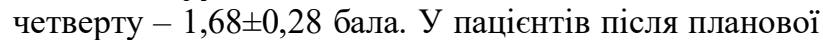
холецистектомії на другу добу після оперативного втручання оцінка була $1,35 \pm 0,18$ бала, а на четверту $2,23 \pm 0,21$ бала.

9. Підняти об'єкт з підлоги з положення стоячи. 4 бали - здатність впевнено підняти тапок; 3 бали - здатність підняти тапок під контролем; 2 бали неможливість підняти взуття, залишається відстань 25 см (1-2 дюйми) і при цьому зберігається рівновага без підтримки; 1 бал - неможливість підняти взуття, 
при спробах виконання тесту вимагається контроль; 0 балів - неможливість спроби підняти взуття, або потрібна допомога, щоб уникнути падіння. Тестування даної активності у пацієнтів після ургентної холецистектомії на другу добу після оперативного втручання становила $0,55 \pm 0,11$ бала, а на четверту - 1,52 $\pm 0,15$ бала. У пацієнтів після планової холецистектомії на другу добу після оперативного втручання оцінка була $0,94 \pm 0,11$ бала, а на четверту $-1,85 \pm 0,25$ бала.

10. Здатність озирнутися і подивитися назад через праве і через ліве плече в положенні стоячи. Пацієнту необхідно повернутися через ліве плече так, щоб побачити те, що знаходиться безпосередньо позаду нього. Потім повторити поворот через праве плече. Дослідник може вибрати об'єкт, на який потрібно дивитися, безпосередньо позаду обстежуваного. 4 бали - впевнений погляд назад з обох сторін i вага тіла переміщається; 3 бали - впевнений погляд назад $з$ одного боку, з іншого менше зміщення ваги; 2 бали - поворот тільки боком, рівновага зберігається; 1 бал - при повороті потрібно контроль; 0 балів потрібна допомога, щоб уникнути падіння. Тестування даної активності у пацієнтів після ургентної холецистектомії на другу добу після оперативного втручання становила $1,23 \pm 0,12$ бала, а на четверту $2,84 \pm 0,20$ бала. У пацієнтів після планової холецистектомії на другу добу після оперативного втручання оцінка була $1,92 \pm 0,18$ бала, а на четверту $3,07 \pm 0,22$ бала.

11. Поворот на $360^{\circ}$. Поверніться кругом. Пауза. Тепер поверніться в зворотному напрямку. 4 бали - здатність впевнено повертатися $360^{\circ}$ за 4 секунди або менше; 3 бали - здатність впевнено повертатися $360^{\circ}$ за 4 секунди або менше тільки в одну сторону; 2 бали - здатність успішно повертатися $360^{\circ}$, але повільно; 1 бал - потреба в контролі або усній пораді; 0 - потреба в допомозі при повороті. Тестування даної активності у пацієнтів після ургентної холецистектомії на другу добу після оперативного втручання становила $0,71 \pm 0,16$ бала, а на

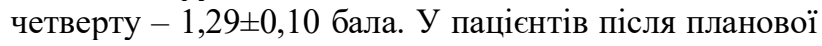
холецистектомії на другу добу після оперативного втручання оцінка була $1,28 \pm 0,11$ бала, а на четверту $2,25 \pm 0,19$ бала.

12. Здатність стояти однією ногою на стільці без підтримки. Пацієнту необхідно помістити по черзі кожну ногу на стілець або табурет і повторити це чотири рази. 4 бали - здатність впевнено зробити 8 кроків за 20 секунд; 3 бали - здатність впевнено зробити 8 кроків, але більш ніж за 20 секунд; 2 бали здатність зробити 4 кроки без допомоги, але під контролем; 1 бал - здатність зробити більше 2 кроків, але 3 мінімальною допомогою; 0 балів - потреба в допомозі, щоб уникнути падіння / неможливість виконати спробу. Тестування даної активності у пацієнтів після ургентної холецистектомії на другу добу після оперативного втручання становила $0,83 \pm 0,09$ бала, а на четверту - 1,06 $\pm 0,11$ бала. У пацієнтів після планової холецистектомії на другу добу після оперативного втручання оцінка була $1,0 \pm 0,13$ бала, а на четверту $1,51 \pm 0,12$ бала.

13. Здатність стояти при тандемному розташуванні стоп. Пацієнту необхідно поставити одну стопу безпосередньо перед іншою. Якщо це неможливо, то спробуйте відступити досить далеко вперед. Щоб оцінка склала 3 бали, довжина кроку повинна перевищити довжину стопи, при розташуванні стоп на ширині плечей. 4 бали - здатність поміщати стопи в тандемне положення і без підтримки стояти 30 секунд; 3 бали - здатність поміщати одну стопу перед іншою без підтримки і стояти 30 секунд; 2 бали здатність зробити маленький крок без підтримки i тримати 30 секунд; 1 бал - потребує допомоги, щоб зробити крок, але може встояти 15 секунд; 0 балів падіння, при кроці або стоячи. Тестування даної активності у пацієнтів після ургентної холецистектомії на другу добу після оперативного втручання станови-

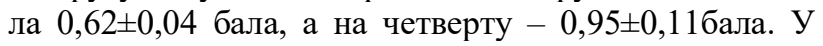
пацієнтів після планової холецистектомії на другу добу після оперативного втручання оцінка була $0,97 \pm 0,09$ бала, а на четверту $-1,54 \pm 0,15$ бала.

14. Здатність стояти на одній нозі. 4 бали здатність без підтримки підняти ногу і стояти більше 10 секунд; 3 бали - здатність без підтримки підняти ногу і стояти 5-10 секунд; 2 бали - здатність без підтримки підняти ногу і стояти 3 секунди або більше; 1 бал - спроба підняти ногу, нездатність ії утримати 3 секунди, рівновага зберігається; 0 балів - неможливість спроби або потреба в допомозі, щоб уникнути падіння. Тестування даної активності у пацієнтів після ургентної холецистектомії на другу добу після оперативного втручання становила $1,03 \pm 0,08$ бала, а на четверту $-1,47 \pm 0,12$ бала. У пацієнтів після планової холецистектомії на другу добу після оперативного втручання оцінка була $1,88 \pm 0,18$ бала, а на четверту - 2,63 $\pm 0,22$ бала.

Інтерпретація шкали: I група - оцінка становить від 0 до 20 балів і відповідає пересуванню за допомогою інвалідного крісла; II група - оцінка становить від 21 до 40 балів і відповідає ходьбі з опорою; III група - оцінка становить від 41 до 56 балів і відповідає ім незалежності у пересуванні. Якщо сумарний бал $\geq 45$ балів - у пацієнта низький ризик падінь, якщо сумарний бал $>45$ балів - високий ризик падінь.

Обговорення результатів. Як відомо, існують дві системи, що відповідають за підтримання стабільності або рівноваги тіла. Однією із них є автоматична система постуральної регуляції. Органи рівноваги (півкруглі канали) і зору, а також механорецептори працюють спільно для подачі в центральну нервову систему необхідної інформації для регуляції діяльності відповідних м'язів $[1,8,9]$.

Інша система заснована на свідомих розумових процесах, що відповідають за забезпечення необхідних дій у певній ситуації. Дані процеси засновані на попередньому досвіді, зафіксованому центральною нервовою системою. Півкруглі канали, розташовані у внутрішньому вусі, його три структури у формі кільця, по одному в кожній площині простору, заповнені рідиною. При зміні положення голови півкруглі канали спрацьовують як нівеліри, використовувані в будівництві, вказуючи кут нахилу в трьох площинах: у горизонтальному положенні (X), вертикально (Y) і в глибину (Z). Зір: очі отримують інформацію про всі положеннях тіла відносно горизон- 
тальної поверхні і навколишніх предметів. Якщо ми стоїмо на одній нозі з закритими очима, то можемо оцінити важливість даної системи в підтримці рівноваги. Пропріоцептивна система містить нескінченну кількість нервових рецепторів (механорецепторів), розташованих в суглобах, м'язах і сухожиллях. Дані рецептори відповідають за збір інформації про просторове положення тіла (суглобові рецептори) і зміни напруги і довжини м'язово-сухожильних з'єднань [1].

На виконання якої-небудь дії залучені три різні групи м'язів: рухові, що відповідають за виконання руху, стабілізуючі, що відповідають за рівноважний розташування частин тіла відносно один одного, i постуральні, функція яких полягає в підтримці вертикального положення тіла і подоланні сили тяжіння. Постуральні м'язи є в першу чергу найглибшими: довгий м'яз шиї, прямі передні м'язи, потиличний м'яз, паравертебральні м'язи, клубовореберний, довгий м'яз спини і попереково-клубовий м'яз. Вони призначені для того, щоб, скорочуючись протягом довгого періоду часу, підтримувати «фундамент», відштовхуючись від якого діють рухові i стабілізуючі м'язи. При відсутності відповідної трофіки глибокі м'язи відносно легко втомлюються, викликаючи перевантаження поверхневих м'язів (виконують частину їх роботи), більш підготовлених до точних рухів, ніж до тривалого скорочення. Постуральні, рухові і стабілізуючі м'язи. Стабілізуюча, постуральна і рухова активність мускулатури надзвичайно складна при здійсненні повсякденної діяльності. Ця активність впливає на численні суглоби, постійно регулює тонус, змушуючи м'язи скорочуватися синергично відносно один одного в залежності від положення тіла і вимог даної ситуації. При опорі на одну ногу, відвідні м'язи зліва спочатку є руховими м'язами. Вони переміщують таз і весь тулуб при нахилі, а потім виконують функцію стабілізаторів для підтримки положення. Відвідні м'язи справа для підтримки рівноваги тіла переміщують ногу в сторону, протилежну нахилу тулуба. Черевні м'язи, квадратний поперековий м'яз, паравертебральні м'язи, клубово-реберний м'яз і довгий м'яз спини праворуч підтримують хребет прямо, утримуючи його від нахилу вліво. Крім того, ці м'язи підтримують положення таза, діючи разом із відвідними м'язами зліва. Потиличні і шийні м'язи переважно зліва стабілізують положення голови і шийних хребців. Відведення рук, за яке відповідальні дельтовидні і надостні м'язи, допомагають підтримувати рівновагу тіла. Обидві руки, в свою чергу, стабілізуються м'язами спини (верхня частина трапецієподібної, ромбовидні), м'яз, що піднімає лопатку, перебуває у нерозслабленому стані, необхідному для швидкої реакції на зміну тонусу і руху верхніх кінцівок для утримання рівноваги. Дорсальні м'язи передпліччя підтримують кисть на одній лінії з усією рукою. М'язи, розташовані нижче коліна, беруть активну участь в контролі рівноваги, завдяки постійній регуляції і координації скорочень (якщо встати на одну ногу, можна відчути дію цих м'язів і постійні рухи щиколотки) [1].

Отже, стає зрозуміло, що тестування рівноваги за допомогою шкали рівноваги Берга здатне ви- явити слабкі ланки у кінематичному ланцюгу, що є причиною обмеження активності у пацієнтів після ЛХЕ.

Аналізуючи результати дослідження, можна зробити висновок, що у ранньому післяопераційному періоді (на 2 добу після оперативного втручання) пацієнти мають виражений ступінь порушення рівноваги. Проте якщо загальний бал у пацієнтів після планової ЛХЕ склав 24,97 бала, то у пацієнтів після ургентної ЛХЕ 18,68 бала. Встановлено статистично значущу різницю між цими двома групами $(\mathrm{p}<0,05)$ як на другий, та і на 4 день після ЛХЕ. Оцінка рівноваги на 4 день після оперативного втручання вказує на позитивну динаміку $((\mathrm{p}<0,05)$, тобто покращення функції, проте ступінь ризику падінь залишається ще досить високим - у групі пацієнтів після планової ЛХЕ 35,54 бала, а у групі пацієнтів після ургентної ЛХЕ 26,91 бала.

\section{Висновки:}

1. У порівнянні із іншими тестами, шкала рівноваги Берга зарекомендувала себе як найбільш переконливий функціональний тест виявлення дисфункцій рівноваги i, на нашу думку, може послужити хорошим інструментом для встановлення індивідуальних цілей у програмі фізичної терапії для пацієнтів після ЛХЕ.

2. У ранньому післяопераційному періоді (на 2 добу після оперативного втручання) пацієнти мають виражений ступінь порушення рівноваги, що обумовлений віком та наявністю супутньої патологї, більш виражений у пацієнтів після ургентної холецистектомії.

3. Оцінка рівноваги на 4 добу після оперативного втручання вказує на позитивну динаміку $(\mathrm{p}<0,05)$, тобто покращення функції, проте ступінь ризику падінь залишається ще досить високим.

4. Високий рівень падіння на стаціонарному етапі реабілітації пацієнтів після лапароскопічної холецистектомії обумовлює необхідність включення у програму фізичної терапії як на стаціонарному, так і на амбулаторному етапах реабілітації методів та засобів, направлених на відновлення функції рівноваги, зміцнення тих м'язів, які відповідальні за постуральну стабільність.

\section{References:}

1. Skvortsov DV, Ivanova GE, Polyaev BA, Stakhovskaya LV. Diagnosis and testing of motor pathology with tools. Journal of Restorative Medicine. 2013; 5:74-78.

2. Adkin AL, Allum JHJ, Bloem BR. Trunk sway measurements during stance and gait tasks in Parkinson's disease. Gait and Posture 2015, 22:240-249.

3. A Four-item falls-risk screening tool for sub-acute and residential care: The first step in falls prevention / C Stapleton, P Hough, K Bull, K Hill, et al. // Australasian Journal on Ageing. 2016; 28(3):139-143.

4. Horlings CG, Küng UM, BG van Engelen, Voermans NC, Hengstman GJ, AJ van der Kooi, Bloem BR, Allum JH. Balance control in patients with distal versus proximal muscle weakness. Neuroscience. 2014; 164(9):18761886. 
УДК 616.366-089.87+616-056.2

\section{РЕЗУЛЬТАТЫ ОЦЕНКИ РАВНОВЕСИЯ У \\ ПАЦИЕНТОВ ПОСЛЕ ЛАПАРОСКОПИЧЕ- СКОЙ ХОЛЕЦИСТЭКТОМИИ НА \\ СТАЦИОНАРНОМ ЭТАПЕ РЕАБИЛИТАЦИИ}

\author{
Н.Р. Голод ${ }^{1}$, И.К. Чурпий ${ }^{1}$, С.О. Кулибаба ${ }^{2}$
}

${ }^{1}$ Ивано-Франковский национальный медицинский университет, кафедра физической реабилитащчи, эрготерапии и физического воспитания, Украина,

ORCID ID: 0000-0003-0996-6920,

ORCID ID: 0000-0003-1735-9418,

e-mail:natasha_777@i.ua,

${ }^{2}$ Винницький национальный медицинский университет им. М.И. Пирогова, кафедра физического

воспитания и ЛФК, г. Винница, Украина,

ORCID ID: 0000-0002-1717-8097,

e-mail:kulibabasergij@gmail.com

Резюме. Цель исследования. Определить риск падений пациентов после лапароскопической холецистэктомии (ЛХЕ) на стационарном этапе реабилитации с помощью шкалы Берген.

Материалы и методы. В исследовании участвовало 30 пациентов после ургентной холецистэктомии и 30 после плановой холецистэктомии, находившихся на стационарном лечении в хирургическом отделении Ивано-Франковской центральной городской клинической больницы. Оценку равновесия проводили применяя Шкалу Берген (BERGBALANCESCALE - BBS), которая включает 14 тестов на 2-е и на 4-е сутки после оперативного вмешательства.

Выводы:

1. По сравнению с другими тестами, шкала равновесия Берга зарекомендовала себя как наиболее убедительный функциональный тест выявления дисфункций равновесия и, по нашему мнению, может послужить хорошим инструментом для установления индивидуальных целей в программе физической терапии для пациентов после ЛХЕ.

2. В раннем послеоперационном периоде (на 2 сутки после оперативного вмешательства) пациенты имеют выраженную степень нарушения равновесия, которая обусловлена возрастом и наличием сопутствующей патологии, более выражена она у пациентов после ургентной холецистэктомии.

3. Оценка равновесия на 4 день после оперативного вмешательства указывает на положительную динамику (р <0,05), то есть улучшение функции, однако степень риска падений остается еще достаточно высокой.

4. Высокий уровень падения на стационарном этапе реабилитации пациентов после лапароскопической холецистэктомии обусловливает необходимость включения в программу физической терапии как на стационарном, так и на амбулаторном этапах реабилитации методов и средств, направленных на восстановление функции равновесия, укрепления тех мышц, которые ответственны за постуральную стабильность.
Ключевые слова: лапароскопическая холецистэктомия, оценка равновесия, реабилитация.

\section{UDC 616.366-089.87+616-056.2 \\ BALANCE ASSESSMENT RESULTS IN PATIENTS AFTER LAPAROSCOPIC CHOLECYSTECTOMY DURING INPATIENT REHABILITATION}

\author{
N.R. Golod ${ }^{1}$, I.K. Churpiy ${ }^{1}$, S.O. Kulibaba \\ ${ }^{1}$ Ivano-Frankivsk National Medical University, \\ Department of Physical Rehabilitation, Ergotherapy and \\ Physical Education, Ukraine, \\ ORCID ID: 0000-0003-0996-6920, \\ ORCID ID: 0000-0003-1735-9418, \\ e-mail: natasha_777@i.ua \\ ${ }^{2}$ National Pirogov Memorial Medical University, \\ Department of Physical Education and Medical Physical \\ Education, Vinnitsa, Ukraine, \\ ORCID ID: 0000-0002-1717-8097, \\ e-mail:kulibabasergij@gmail.com
}

Abstract. One of the most important functions that significantly affects a patient's motor performance after laparoscopic cholecystectomy (LCE) is postural equilibrium. The development of a physical therapy program for patients after LCE requires tests that will assess the ability to perform daily tasks, identify the risk of downfalls, and also reflect the impact of temporary disability on the overall patient's health and quality of life. The use of clinical tests to assess patient's equilibrium in the process of physical therapy is necessary to formulate the goals of physical therapy and to evaluate the effectiveness of the implemented rehabilitation program.

The Bergen scale (BERGBALANCESCALE $\mathrm{BBS}$ ) includes 14 tests that require to maintain body in various positions and to perform specific tasks.

Aim of the study is to determine the risk of patients' downfall after LCE at the inpatient rehabilitation stage using the Bergen scale.

Materials and methods. The study involved 30 patients after urgent cholecystectomy and 30 patients after scheduled cholecystectomy who were hospitalized in the surgical department of the Ivano-Frankivsk central city clinical hospital. The equilibrium assessment was performed on the second and fourth day after surgery.

Exclusion criteria - patients with concomitant neurological diseases, severe condition of the patient.

The score was based on the patient's ability to perform 14 tasks independently after LCE, or to do them according to specific time and distance requirements. Each component was rated on a five-point scale from 0 to 4, so total scores ranged from 0 to 56 .

Analyzing the results of the study, it becomes clear that in the early postoperative period ( 2 days after surgery) patients in both groups have a marked degree of impaired balance. However, in patients after urgent LCE, it is more pronounced. A statistically significant difference was found between the two groups $(p<0.05)$ both on the second and on day 4 after LCE. An evaluation of equilibrium on day 4 after surgery indicates a positive 
trend $((\mathrm{p}<0.05)$, i.e. improvement in function, however, the risk of downfalls in two groups is still quite high, which obviously requires the development and implementation of a physical therapy program for these patients.

\section{Conclusions:}

1. In comparison to other tests, Berg's equilibrium scale has proven to be the most convincing functional test for the detection of equilibrium disfunctions and, in our opinion, can serve as a good tool for setting individual goals in a physical therapy program for patients after LCE.

2. In the early postoperative period ( 2 days after surgery) patients have a pronounced degree of impaired balance, which is due to age and concomitant pathology, more pronounced in patients after urgent cholecystectomy.

3. An equilibrium score on day 4 after surgery indicates a positive trend $(\mathrm{p}<0.05)$, i.e. improvement in function, however, the risk of falls remains quite high.

4. The high level of downfall at the inpatient stage of rehabilitation after laparoscopic cholecystectomy necessitates the inclusion of methods and means aimed at restoring equilibrium function and muscle balance stability to the program of physical therapy both at the inpatient and outpatient stages of rehabilitation.

Keywords: laparoscopic cholecystectomy, equilibrium assessment, rehabilitation.

Стаття надійшла в редакцію 10.09.2019 р. 